\title{
Analysis of Perceived Factors Affecting Tourist Satisfaction in Mountain Tourism: A Study In Mount Papandayan, Indonesia
}

\author{
Afina Putri Vindiana, Santi Novani, Lidia Mayangsari, \\ and Dini Turipanam Alamanda
}

School of Business and Management, Bandung Institute of Technology

Corresponding author: afina_putri@sbm-itb.ac.id

\begin{abstract}
ARTICLE INFO
Received

02 January 2020

Accepted

18 March 2020

Available online

31 March 2020
\end{abstract}

\begin{abstract}
Although the mountain is a popular tourist destination, research regarding mountain tourism is still limited. Over the years, researches on tourist satisfaction covered a more general context of tourism, without specifically analyzing mountain tourism. Therefore, this research aims to investigates factors influencing tourists' satisfaction on mountain tourism, with Mount Papandayan, Garut Regency, West Java, Indonesia, as a case. Eleven variables regarding tourist satisfaction were derived from several interviews with Mount Papandayan's management staff and 30 tourists that were hiking and camping on Mount Papandayan. A sample of 100 respondents, who were the Mount Papandayan's tourists that had been hiking and camping, completed questionnaires. Exploratory factor analysis (EFA) and confirmatory factor analysis (CFA) was used to analyze the data. The results show that there are three factors that affect tourist's satisfaction in mountain tourism, which are 'infrastructure and facilities', 'natural resources', and 'mountain area's atmosphere', while CFA validated the model fit. The results also indicated a significant relationship between the three factors. This research provides an opportunity for broader research opportunities in mountain tourism, especially in tropical countries.
\end{abstract}

Keywords : mountain tourism, satisfaction, EFA, CFA.

\section{INTRODUCTION}

\section{Background}

Mountain is one of the most popular tourist destinations, with its beautiful view and atmosphere. Having the mountainous region as a tourist http://ojs.unud.ac.id/index.php/eot destination is important to create sustainable development for an area where resources are limited (Messerli \& Ives, 1997). Other than that, once a mountain is set as a tourist destination, there will be beneficial actions done such as environmental protection in order to 
preserve the authenticity of the destination. According to UNWTO, tourism in the mountainous area is called 'mountain tourism', and it offers typical activities according to the environment of the mountain. This means the activities offered in tropical countries are different to those offered in subtropical countries. However, there is an ongoing problem between mountain tourism in subtropical and tropical countries. Tourists nowadays seem to favor snow-related activities which are only found in mountain tourism in subtropical countries, leaving tourism activities in tropical mountain unpopular (Fredman \& Heberlein, 2003).

Indonesia, as one of the tropical countries, lies in the legendary area called "The Ring of Fire" with 452 active and dormant volcanoes, which means it has a lot of developing mountain tourism areas. Mountain tourism becomes an important part of the overall tourism industry as 20 percent of tourists are mountainous regions' tourists (Silva, Kastenholz \& Luís, 2015).

In order to maintain the sustainability of tourism in tropical countries' mountain regions, where there are no winter-themed outdoor activities included, factors that influence tourist's satisfaction after visiting the mountain area should be investigated. It is widely believed that a high level of tourist http://ojs.unud.ac.id/index.php/eot satisfaction will maintain the loyalty of the tourists (Wiranatha et al., 2018; Wiranatha et al., 2016; Suryawardani et al., 2017), create the intention to revisit and get them to spread positive word of mouth (Baker \& Crompton, 2000; Del Bosque \& San Martin, 2008) .

\section{Research Objectives}

Development of a new perspective of mountain tourism becomes an exciting endeavor, especially the studies on what makes tourists feel satisfied with mountain tourism. Therefore, the aim of this study is to identify factors affecting the satisfaction of tourists who choose mountain tourism for vacation and empirically validate the model of tourist satisfaction in mountain tourism. This research measure tourist satisfaction with more objective variables than previous researches, which usually focused on expectation-perceived experience model or cognitive-affective, emotional-related model (Kozak \& Rimmington, 2000). By studying factors influencing tourist satisfaction in a specific context, the future development of mountain tourism could be on target and eventually, increasing the number of tourists. This study uses Mount Papandayan for its case, as it is one of the most developed mountain regions in Indonesia and one of the most popular sites for mountain tourism. 


\section{LITERATURE REVIEW}

\section{Tourist Satisfaction}

To maintain the loyalty of the tourists, tourist satisfaction's level must be high enough, thus making research in tourist satisfaction quickly grows since the 1980 s as it is assumed to be directly related to competitive advantage a destination has (Baker \& Crompton, 2000; Del Bosque \& San Martin, 2008). At the beginning of the tourist satisfaction research era, tourist satisfaction was considered as an emotional experience and cognitive judgments of the destination with negative or positive emotions as the output that defines the satisfaction variable (Oliver, 1993). The difference that tourists expect and what the real experience of tourists was also perceived as another way to measure tourist satisfaction (Oliver, 1980; Wirtz, Mattila \& Tan 2000), but it is rejected by many researchers due to being too subjective (Johns, Avci \& Karatepe, 2004). Meanwhile, Gronroos (1990) started to think that the measurement for customers (or tourists in tourism context) satisfaction is the outcome of the certain quality of service and its perception by customers.

The importance of measuring tourist satisfaction increases in the context of quality. The poor performance provided by one of the elements of a tourist http://ojs.unud.ac.id/index.php/eot destination could create a 'halo effect': a condition where tourists' dissatisfaction with a destination's component makes tourists feel dissatisfied with the overall tourism experience and elements (Cohen, 2013). This phenomenon makes a new era of tourist satisfaction research in quality of performance rather than emotional-related. The identification of destination's elements are significant in defining overall tourist satisfaction, yield managers' support to decide on investing for improvement of tourist destination, thus increasing the competitiveness of the destination (Bernini \& Cagnone, 2014).

This research aims to measure tourist satisfaction with tourism products and atmosphere as the main variables, which are considered more reliable than previous research on expectationperceived experience model or cognitiveaffective, emotional-related model in tourist satisfaction (Kozak \& Rimmington, 2000).

\section{Tourist Satisfaction on Mountain Tourism}

The number of researchers that conduct studies in mountain tourism is increasing since the beginning of the 2000s (Godde, Price \& Zimmermann, 2000; Beedie \& Hudson, 2003; Nepal, 2003), even though most of them only cover the nature conservation of mountain 
area. The development of a new perspective of mountain tourism, therefore, becomes an exciting endeavor, especially regarding the tourists' behaviour toward mountain tourism.

Tourism prospects in the mountain area are getting higher, and one of the attractiveness of mountain is related to its beauty of nature. Fredman (2008) stated that the beautiful view a destination could offer would give a significant amount of total outdoor experience. This means mountain tourism has significant opportunities to give total satisfaction to tourists, by combining stunning scenery with high quality of service. The value of mountain tourism is very substantial as about 20 percent of the tourist industry, per year, is elucidated by mountain tourism (Silva, Kastenholz \& Luís, 2015).

As mentioned before, investigating tourist satisfaction could influence the loyalty of tourists and create the intention to revisit. Mountain tourism, although still gaining popularity, has lost some of its tourists (Fredman \& Heberlein, 2003), thus it is urgent to research regarding tourists' intention to revisit-which begins with what influences tourist satisfaction in mountain tourism.

Research in the mountainous landscape as a tourist destination rarely came across the management aspect, especially tourist's satisfaction http://ojs.unud.ac.id/index.php/eot
(Smethurst, 2000). Meanwhile, a study in tourist satisfaction usually deals with a more general concept of tourism, which sometimes does not apply to the mountain tourism context. Nevertheless, the number of researchers that conduct studies on mountain tourism is increasing since the beginning of the 2000s. Previous research in mountain tourism has discussed the conceptual framework of mountain tourism (Nepal \& Chipeniuk, 2005), which later expands to the perception of residents living near mountain destinations (Silva, Kastenholz \& Luís, 2015). Research in mountain tourism's sustainability and accommodation was also conducted (Dornier \& Selmi, 2018), and the emotional-related research that explains tourists' experience in mountain tourism (Frochot, Elliot \& Kreziak, 2017).

\section{METHODOLOGY}

Prior to collecting the data, several semi-structured interviews regarding tourist satisfaction were conducted with Mount Papandayan Tourism Management's staff and 30 domestic tourists that were hiking and camping on Mount Papandayan. The interviews were conducted in Bahasa Indonesia in a spot inside the Mount Papandayan's site that was quite secluded to diminish unnecessary noises on the interviews' 
recording. The interviewees were informed of some important information regarding the interviews, such as the objectives and confidentiality of the interviews, how the interviews took some time and were recorded and transcribed for further analysis.

Based on the interviews, a total of 11 variables were included in the final questionnaire:
1) fresh air
2) view
3) cleanliness
4) photogenic spot
5) direction board
6) restaurant
7) crater
8) destination for families
9) forest
10) flower garden
11) safe trekking route

Some of the variables derived from interview results were selected in accordance with previous literature on tourism. For example, "cleanliness" was selected because Tasci, Gartner, \& Cavusil (2007) mentioned that cleanliness of the environment and maintenance of public facilities is one of the attributes that represent tourist's satisfaction. "Direction board" was also inserted as a variable because Bagri \& Kala (2015) claimed that it is important to see if tourists are satisfied http://ojs.unud.ac.id/index.php/eot with the current direction board and signage that are embedded in the tourism spot.

After the questionnaire was finalized, a survey was conducted in Mount Papandayan to collect data. Respondents were selected using purposive sampling, where domestic tourists were asked first if they had been hiking and camping on Mount Papandayan. Likert scale was used on the questionnaires, ranging from 1 to 4 , with 1 as "strongly disagree" and 4 as "strongly agree". Even-numbered Likert scale was chosen to urge the respondents to choose between agree and disagree, preventing neutral position that usually occurs in an odd-numbered Likert scale (Brown, 2000). A sample of 100 respondents was collected from the survey. Exploratory factor analysis (EFA) was selected to group several observed variables into relevant factors. EFA also gives the possibility for the researcher to consider cultural differences and research settings (Hadi, Abdullah \& Sentosa, 2016). Confirmatory Factor Analysis (CFA) was used to validate the proposed model from EFA results. EFA was conducted using IBM SPSS Version 23.0, while CFA was performed using AMOS 23. 


\section{RESULTS AND DISCUSSION}

Based on the profile of the respondents, most of them came from Jakarta, the capital of Indonesia. The majority of the tourists get information about Mount Papandayan from their friends, which could be a sign for a positive effect of word of mouth (WOM).

Table 1. Respondents' Profile $(\mathrm{N}=100)$

\begin{tabular}{ll}
\hline Variable & $\%$ \\
\hline Gender & \\
\hline Male & 72 \\
Female & 28 \\
\hline City of Residence & \\
\hline Jakarta & 22 \\
Bandung & 18 \\
Garut & 14 \\
Tasikmalaya & 12 \\
Bekasi & 8 \\
Other & 26 \\
\hline Information Source & \\
\hline Friends & 70 \\
Family & 4 \\
Social Media & 22 \\
\hline
\end{tabular}

Source : Data Analysis (2019)

After identifying the profile of the respondents, EFA was performed to sort variables into several factors. Principal component and varimax rotation were used to investigate orthogonal factor dimensions. The number of factors is extracted based on eigenvalues greater than 1.0 , rotated by varimax analysis. Cutoff for factor loadings is set to 0.50 as it is perceived as an excellent cut-off to decrease the probability of cross-loadings (Kalia, 2017).
Eleven variables regarding satisfaction resulted in three-factor groupings: "infrastructure facilities", "natural resources", “mountain area's atmosphere", and explained $61.232 \%$ of the variance. From the results of grouping variables into factors (Table 2), variables related to the destination attractions such as crater and flower garden are grouped under the same factor, while variables regarding what tourists feel or see are assembled into another factor. The same goes for variables concerning facilities such as restaurants or food stalls, direction board, and trekking route.

Table 2. Exploratory Factor Analysis Results

\begin{tabular}{llll}
\hline Factors & $\begin{array}{l}\text { Factor } \\
\text { Loading }\end{array}$ & $\begin{array}{l}\text { Eigen } \\
\text { Value }\end{array}$ & $\begin{array}{l}\text { \% of } \\
\text { Variance }\end{array}$ \\
\hline F1: Infrastructure & & 4.398 & 39.980 \\
Facilities & & & \\
\hline Cleanliness & 0.666 & & \\
Direction Board & 0.713 & & \\
Restaurant & 0.592 & & \\
Safe Trekking & 0.724 & & \\
Route & & & \\
Destination for & 0.678 & & \\
Families & & & \\
\hline F2: Natural & & 1.316 & \\
Resources & & & \\
\hline Forest & 0.644 & & \\
Flower Garden & 0.850 & & \\
Crater & 0.675 & & \\
\hline F3: Mountain & & 1.021 & 9.286 \\
Area's & & & \\
Atmosphere & & & \\
\hline Fresh Air & 0.652 & & \\
View & 0.638 & & \\
Photogenic Spot & 0.862 & & \\
\hline Total Variance Explained & & \\
\hline
\end{tabular}

Source: Data Analysis (2019) 
Factor loadings were ranging from 0.592 to 0.862 , which means the correlations between the items and the factor groupings are good. Commonalities of the variables were ranging from 0.522 to 0.764 , indicating a moderate fit between variables within a component. To measure the construct validity, convergent validity and discriminant validity were conducted. Convergent validity of each construct was determined by analyzing AVE and composite reliability.

Table 3. Composite Reliability and AVE of Constructs

\begin{tabular}{lll}
\hline Factors & AVE & $\begin{array}{l}\text { Composite } \\
\text { Reliability }\end{array}$ \\
\hline Infrastructure Facilities & 0.457 & 0.807 \\
Natural Resources & 0.531 & 0.769 \\
Mountain Area's & 0.525 & 0.764 \\
\hline Atmosphere & & \\
\hline
\end{tabular}

Source : Data Analysis (2019)

From Table 3, "Natural Resources" and "Mountain Area's Atmosphere" had good value of AVE and composite reliability, as the minimum value of AVE and composite reliability is 0.5 and 0.7 , respectively (Fornell \& Lacker, 1981). However, "infrastructure facilities" has AVE lower than 0.5 , but the composite reliability passed the minimum criteria, so it is still acceptable (Fornell \& Lacker, 1981). The discriminant validity was assessed by calculating the shared variance between the constructs.
Table 4. Correlation and Shared Variance Between Constructs

\begin{tabular}{|c|c|c|}
\hline Factors & $\begin{array}{l}\text { Coefficient of } \\
\text { correlation }\end{array}$ & $\begin{array}{l}\text { Shared } \\
\text { Variance }\end{array}$ \\
\hline $\begin{array}{l}\text { Infrastructure } \\
\text { Facilities - } \\
\text { Natural } \\
\text { Resources }\end{array}$ & 0.479 & 0.229 \\
\hline $\begin{array}{l}\text { Natural } \\
\text { Resources -- } \\
\text { Mountain } \\
\text { Area's } \\
\text { Atmosphere }\end{array}$ & 0.419 & 0.175 \\
\hline $\begin{array}{l}\text { Infrastructure } \\
\text { Facilities -- } \\
\text { Mountain } \\
\text { Area's } \\
\text { Atmosphere }\end{array}$ & 0.320 & 0.102 \\
\hline
\end{tabular}

The AVE of each construct is higher than the shared variance between the constructs shown in Table 4. Based on that results, it can be concluded that the discriminant validity of the constructs is established (Fornell \& Lacker, 1981). First-order CFA was performed to analyze the model constructed by EFA results.

The results showed a fit for the tested model, with significant Chisquare/df less than 2 (Byrne, 2013), RMSEA (root mean square error of approximation) less than 0.08, and GFI (goodness of fit index), CFI (comparative fit index), and TLI (Tucker Lewis Index) more than 0.90 (Table 5). The AGFI (adjusted goodness of fit index) however, has the value lower than 0.90 , but it is still categorized as marginal fit since the value is higher than 0.80 .

e-ISSN: 2407-392X. p-ISSN: 2541-0857 
Table 5. CFA Fit Results

\begin{tabular}{lll}
\hline Indicator & Value & Note \\
\hline CMIN/df $(<2)$ & 1.167 & Fit \\
RMSEA $(<0.08)$ & 0.041 & Fit \\
GFI $(>0.90)$ & 0.919 & Fit \\
CFI $(>0.95)$ & 0.977 & Fit \\
TLI $(>0.90)$ & 0.969 & Fit \\
AGFI $(>0.90)$ & 0.870 & Marginal \\
& \multicolumn{2}{c}{ Fit } \\
\hline
\end{tabular}

Source: Data Analysis (2019)

The first-order CFA also showed a three-factor model that defines the data, with good correlation between each factor (Figure 1).

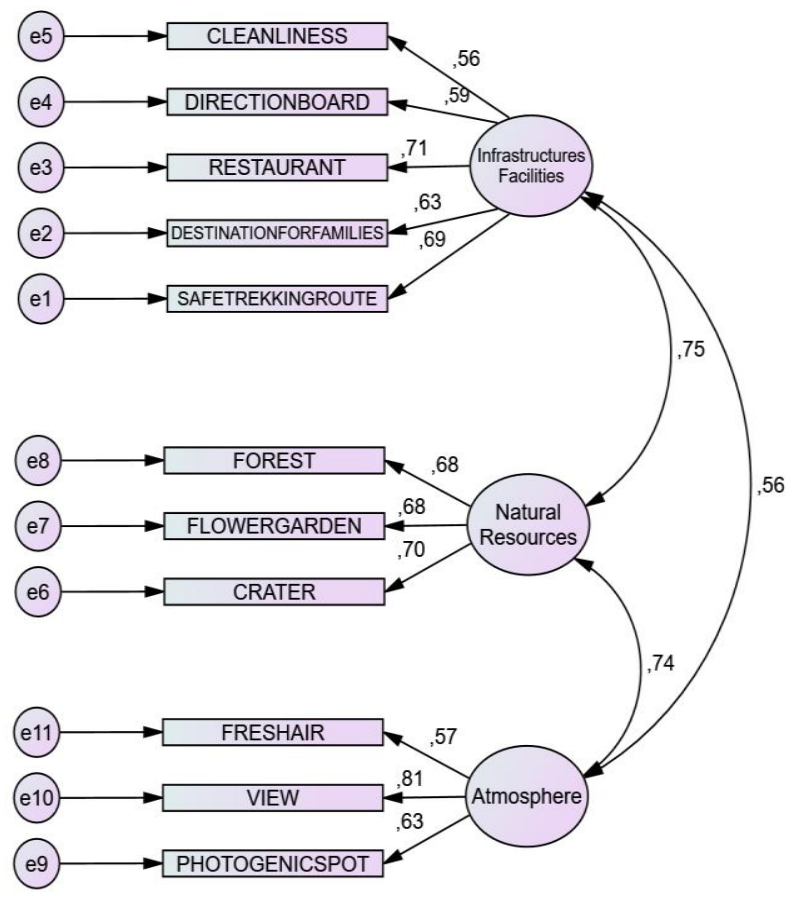

Figure 1. CFA model with standardized regression coefficients

From the model, it could be interpreted that "Infrastructure Facilities" factor is significantly correlated with "Natural Resources" (0.75), and so "Natural Resources" is significantly http://ojs.unud.ac.id/index.php/eot correlated with "Mountain Area's Atmosphere" (0.74). "Infrastructure Facilities" is also positively correlated to "Mountain Area's Atmosphere" (0.56). The results indicated that "Natural Resources" have the most significant relationship to the other factors, so management staffs of Mount Papandayan should maintain the natural resources seriously, as it significantly affects other factors of tourists' satisfaction in mountain tourism. The standardized correlation coefficients results showed that the each variable is significant since the $p$-value is lower than 0.001, with "Restaurant" as the most important variable in "Infrastructure Facilities" factor (0.713), while variable named "Crater" is the most significant among the other variables under "Natural Resources" factor (0.70). Lastly, the third factor, "Mountain Area's Atmosphere", has variable "View" as the most important one (0.81).

Finding on how restaurant is seen as the most important aspect on destination's facilities and infrastructure is aligned with previous study by Faulkner, Oppermann, \& Fredline (1999). Tourist destination should highlight the restaurant or cuisine as its tourism product, as tourists' interest on food in tourist destination grows bigger. Previous research even claimed that a destination that could provide restaurants with good e-ISSN: 2407-392X. p-ISSN: 2541-0857 
experience will make the tourists feel more satisfied with the destination. Meanwhile, crater is seen as the most important natural resource for tourists visiting mountain region. It could be seen as accurate, considering crater is a unique property owned by a mountain. A unique resource makes a tourist destination as alluring to some of the tourists, thus in this case, mountain is a potential tourist destination as it has many unique resources that another area doesn't (Swaarbrooke, 1995).

The three factors contributing to tourist satisfaction on mountain tourism are all supported by previous studies on tourism. In Southeast Europe, destination's infrastructure correlates to the success of its development, since better infrastructure means better production and distribution of services in the destination (Jovanović \& Ivana, 2016). High investment in creating new infrastructure and facilities will likely bring more tourists to come, especially hotel rooms. Surprisingly, variables called "destination for families" and "cleanliness" were included in infrastructure factor, which means the destination's facilities and infrastructure should be family-friendly and has good hygiene.

"Natural resources" as a factor regarding tourist satisfaction from this study, is aligned with previous research that dotted natural resources as the primary http://ojs.unud.ac.id/index.php/eot element for tourists to come (Mihalič, 2013), though it is also implied that due to uncertain behavior of nature, other aspects from the destination such as services and infrastructure should be improved to create satisfaction among tourists, as bad infrastructure relates to lower tourist satisfaction, which suits the result of this research (Coghlan, 2012).

The last factor, "Mountain area's atmosphere", is supported by previous research (Becken, 2010) about how the climate and weather of a tourist site is important in determining tourist's decision to visit it. Tourists will not choose a tourist destination that often has bad weather or climate since it prevents them to enjoy the site and poses many risks. Mount Papandayan has fresh air and beautiful view that is protected well enough for tourists to enjoy, and it is important to keep the atmosphere of Mount Papandayan the way it is, as changes in atmosphere, according to Becken (2010), will cause loss of prospective tourists.

\section{CONCLUSION}

Tourist satisfaction in mountain tourism can be seen from three factors: "Infrastructure and Facilities", "Natural Resources", and "Mountain Area's Atmosphere". These three factors are significantly correlated with one another, 
so a sufficient maintenance is needed on these factors to increase tourists' satisfaction in mountain tourism, especially the natural resources, which have a stronger influence toward other factors. Mountain's crater, forest, and flower garden, which are the site's natural resources, should be maintained carefully, as those features are what makes tourists feel satisfied after visiting mountain area.

Future research should consider including two or three sites of mountain tourism as study case. Further research could also implies a second-order factor analysis to analyze tourist satisfaction toward mountain tourism.

\section{REFERENCES}

Bagri, S. C., Kala, D. (2015). Tourists' satisfaction at Trijuginarayan, India: An importance-performance analysis. Advances in Hospitality and Tourism Research, 3(2), 89-115.

Baker, D. A., \& Crompton, J. (2000). Quality, satisfaction, and behavioral intentions. Annals of Tourism Research, 27(3), 785-804.

Becken, S. (2010). The importance of climate and weather for tourism. Land Environment and People (LEaP) background paper, Lincoln University, 4-13.

Beedie, P., \& Hudson, S. (2003). Emergence of mountain-based adventure tourism. Annals of tourism research, 30(3), 625-643.
Bernini, C., Cagnone, S. (2014). Analysing tourist satisfaction at a mature and multi-product destination. Current Issues in Tourism, 17(1), 1-20.

Brown, J. D. (2000). What issues affect Likert-scale questionnaire formats. Shiken: JALT Testing \& Evaluation SIG Newsletter, 4(1), 27-30.

Byrne, B. M. (2013). Structural equation modeling with LISREL, PRELIS, and SIMPLIS: Basic concepts, applications, and programming. Psychology Press.

Coghlan, A. (2012). Linking natural resource management to tourist satisfaction: a study of Australia's Great Barrier Reef. Journal of Sustainable Tourism, 20(1), 41-58.

Cohen, J. (2013). Statistical power analysis for the behavioral sciences (2nd ed). Routledge.

Del Bosque, I. R., San Martin, H. (2008). Tourist satisfaction: A cognitiveaffective model. Annals of Tourism Research, 35, 551-573.

Dornier, R., \& Selmi, N. (2018). Peer-topeer accommodation and sustainability in mountain areas. Worldwide Hospitality and Tourism Themes, 10(2), 259-266.

Faulkner, B., Oppermann, M., \& Fredline, E. (1999). Destination competitiveness: An exploratory examination of South Australia's core attractions. Journal of Vacation Marketing, 5(2), 125-139.

Fornell, C. R., \& Lacker, D. F. (1981). Two structural equation models with unobservable variables and measurement error. Journal of Marketing Research, 18(1), 39-50. 
Fredman, P., \& Heberlein, T. A. (2003). Changes in skiing and snowmobiling in Swedish mountains. Annals of tourism research, 30(2), 485-488.

Fredman, P. (2008). Determinants of visitor expenditures in mountain tourism. Tourism Economics, 14(2), 297-311.

Frochot, I., Elliot, S., \& Kreziak, D. (2017). Digging deep into the experience-flow and immersion patterns in a mountain holiday. International Journal of Culture, Tourism and Hospitality Research, 11(1), 81-91.

Godde, P. M., Price, M. F. and Zimmermann, F.M. (2000). Tourism and Development in Mountain Regions, Wallingford, UK: CABI Publishing.

Gronroos, C. (1990). Service management and marketing: Managing the moments of truth in service competition. Lexington: Lexington Books.

Hadi, N. U., Abdullah, N., Sentosa, I. (2016). An easy approach to Exploratory Factor Analysis: marketing perspective. Journal of Educational and Social Research, 6(1), 215.

Johns, N., Avci, T., \& Karatepe, O. M. (2004). Measuring service quality of travel agents: evidence from Northern Cyprus. The Service Industries Journal, 24(3), 82-100.

Jovanović, S., \& Ivana, I. L. I. Ć. (2016). Infrastructure as important determinant of tourism development in the countries of Southeast Europe. Ecoforum Journal, 5(1).
Kalia, P. (2017). Service quality scales in online retail: methodological issues. International Journal of Operations \& Production Management, 37(5), 630663.

Kozak, M., \& Rimmington, M. (2000). Tourist satisfaction with Mallorca, Spain, as an off-season holiday destination. Journal of travel research, 38(3), 260-269.

Messerli B. \& Ives, J. D. (1997). Mountains of the World: A Global Priority. Carnforth: Parthenon.

Mihalič, T. (2013). Performance of Environmental Resources of a Tourist Destination. Journal of Travel Research, 52(5), 614-630.

Nepal, S. K. (2003). Strategies for mountain ecotourism development, in Ranga $M$. and Chandra D. (Eds) Tourism and Hospitality in the 21st Century, 135-154. New Delhi: Discovery Publishing.

Nepal, S. K., \& Chipeniuk, R. (2005). Mountain tourism: Toward a conceptual framework. Tourism Geographies, 7(3), 313-333.

Oliver, R. L. (1993). Cognitive, affective, and attribute bases of the satisfaction response. Journal of Consumer Research, 20(3), 418-430.

Oliver, R. L. (1980). A cognitive model of the antecedents and consequences of satisfaction decisions. Journal of Marketing Research, 17(4), 46-49.

Silva, C., Kastenholz, E., \& Luís Abrantes, J. (2015). Residents' perceptions of mountain destinations. Marketing Places and Spaces. UK: Emerald Group Publishing Limited. 
Smethurst, D. (2000). Mountain geography, The Geographical Review, 90(1), 35-56.

Suryawardani, I. G. A. O., Wiranatha, A. S., Bendesa, I. K. G., Antara, M., \& Gravari-Barbas, M. (2017). A Structural Model of Foreign Tourists' Loyalty in Nature-Based Tourism in Bali. International Journal of Applied Business and Economic Research, 15(19), 195-214.

Tasci, A. D., Gartner, W. C., \& Cavusgil, S. T. (2007). Measurement of destination brand bias using a quasiexperimental design. Tourism Management, 28(6), 1529-1540.

Wiranatha, A. S., Bendesa, I. K. G., \& Suryawardhani, I. G. A. O. (2018). Model of Foreign Tourists' Loyalty in Cultural and Heritage Tourism in Bali. Global and Stochastic Analysis, 5(8), 73-92.

Wiranatha, A. S., Suryawardani, I. G. A. O., Bendesa, I. K. G., \& Antara, M. (2016). Model of Foreign Tourist's Loyalty on Marine Tourism to Visit Bali. International Journal of Multidiciplinary Education Research, 5(3), 1-16.

Wirtz, J., Mattila, A. S., \& Tan, R. L. (2000). The moderating role of targetarousal on the impact of affect on satisfaction-an examination in the context of service experiences. Journal of retailing, 76(3), 347-365. 